\title{
PARADIGMAVÁLTÁS SZÜKSÉGESSÉGE A TUDOMÁNYOS TELJESÍTMÉNY ÉRTÉKELÉSE SORÁN
}

\section{THE NEED OF PARADIGM SHIFT IN ASSESSMENT OF SCIENTIFIC OUTPUT}

\author{
Magura Tibor \\ az MTA doktora, Debreceni Egyetem Ökológiai Tanszék \\ magura.tibor@science.unideb.hu
}

\begin{abstract}
ÖSSZEFOGLALÁS
A környezettudomány és ökológia tudomány-részterületen az 1980-as évektől a magyar levelezési című szerzők tudományos publikációinak átlagos szerzőszáma a többi, magyar levelezési című szerzőt nem tartalmazó publikáció átlagos szerzőszámához képest szignifikánsan nagyobb mértékben nőtt. A publikációk szerzőszámának növekedésével nő a valószínűsége annak, hogy olyan is társszerzőként szerepel a közleményben, aki nem teljesíti a szerzőségi kritériumokat. A szerzőségi kritériumok be nem tartása és ebből adódóan a ki nem érdemelt szerzőség az etikai problémákon kívül a tudományos kommunikációs rendszer hitelességét és a tudományos teljesítmény objektív megítélését is veszélyezteti. A napjainkban általánosan elfogadott, a szerzők hozzájárulását mellőző, súlyozatlan kredit-hozzárendelésen alapuló tudományos teljesítményt mérő módszer elavult, igazságtalan, és elősegíti a szerzőséget érintő visszaéléseket. Emiatt a tudományos teljesítmény értékelése során paradigmaváltásra van szükség, a szerzői hozzájárulás mértékének figyelembevétele elengedhetetlen a publikációk után járó kreditek (tudománymetriai mérőszámok) elosztásánál.
\end{abstract}

\section{ABSTRACT}

In the environmental sciences and ecology papers since the 1980s the average number of Hungarian scientist(s) as authors of has increased more significantly than in papers without Hungarian scientist(s). The probability of a paper containing a coauthor that does not meet authorship guidelines increases significantly with the number of authors per paper. Non-compliance with authorship guidelines and undeserved authorship brings up not only ethical issues, but damages both the authenticity of scientific communication system and the objective assessment of scientific output of individual scientists. In assessment and ranking of individual scientists, the nowadays generally accepted and used full counting scheme (each author gets full credit for a paper) is apparently unfair, and contributes to authorship abuses and to unjustified inflation of coauthors. To suppress a tendency to 'byline banditry' author contributions should be considered during the assessment and ranking of researchers. The methodology of this fractional or authorship-weighted counting scheme (distributing credit of publication among coauthors according to the rank of authors) has been already developed, there is only an urgent need for paradigm shift in the assessment of scientific output. 
Kulcsszavak: publikáció szerzőszáma, szerzőségi kritériumok, ki nem érdemelt szerzőség, szerzői hozzájárulás mértéke, szerzői hozzájáruláson alapuló értékelési módszer

Keywords: number of authors in papers, authorship guidelines, undeserved authorship, author contributions, authorship-weighted counting scheme

\section{BEVEZETÉS}

A tudományos eredmények közzététele alapvető fontosságú a tudomány fejlödésének szempontjából, hiszen elméleti és/vagy tapasztalati alapot szolgáltat új hipotézisek, összefüggések megalkotásához, vizsgálatához. Számos formája létezik az eredmények közlésének, de a kutatók számára a legfontosabb a független szakértők által értékelt tudományos folyóiratokban (peer-reviewed journals) való publikálás. Az ilyen publikációk száma, minősége és visszhangja a kutatók teljesítményének legfontosabb mérőeszközei. Ezek a mérőszámok meghatározzák a kutató elismertségét, előmenetelét és pályázati sikerességét is (Duffy, 2017). Ebből adódóan a kutatói társadalom tagjaira folyamatos publikálási kényszer nehezedik (vö. publish or perish frázis).

\section{A PUBLIKÁCIÓS KÉNYSZER HATÁSAI}

A publikációs kényszer hatására a kutatók arra törekednek, hogy minél több publikációban szerzők legyenek. Így a publikációk száma, a publikációk átlagos szerzőszáma és a tömegszerzős publikációk aránya is folyamatosan nő (Cronin, 2001). Ezekkel párhuzamosan az egyszerzős cikkek aránya drasztikusan csökken. A környezettudomány és ökológia területén is hasonló tendenciát figyelhetünk meg. A nyolcvanas évektől a tudományos publikációk száma ( 1 . ábra a; $\left.\mathrm{F}_{3,37}=15019,279, \mathrm{p}<0,001, \mathrm{R}^{2}=0,997\right)$ és a publikációk átlagos szerzöszáma kvadratikusan (1. ábra b; $\mathrm{F}_{3,37}=57815,727, \mathrm{p}<0,001, \mathrm{R}^{2}=0,997$ ), a tömegszerzős (> 50 szerzö) publikációk aránya exponenciálisan nőtt (1. ábra c; $\left.\mathrm{F}_{4,37}=144,097, \mathrm{p}<0,001, \mathrm{R}^{2}=0,923\right)$, míg az egyszerzős publikációk aránya nemlineárisan csökkent (1. ábra d; $\mathrm{F}_{4,37}=4694,061, \mathrm{p}<0,001, \mathrm{R}^{2}=0,990$ ).

\section{A PUBLIKÁCIÓK ÁTLAGOS SZERZŐSZÁM-NÖVEKEDÉSÉNEK OKAI}

Napjaink modern kutatásai egyre komplexebb kérdéseket vizsgálnak, egyre gyakrabban alkalmazzák a különbözö tudományterületek módszereit, és vonják be a tudományterületek specialistáit, valamint egyre gyakrabban nemzetközi 
együttműködésben valósulnak meg. Az ilyen, multidiszciplináris kutatások hozzájárulhatnak a kutatás eredményeiből létrejövő publikációk átlagos szerzőszámának növekedéséhez (Logan et al., 2017).
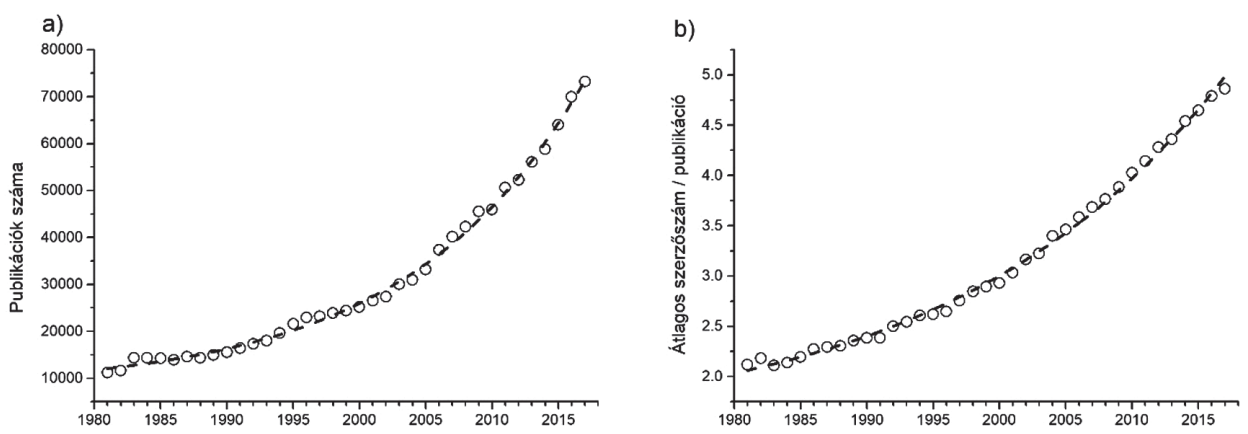

c)

d)
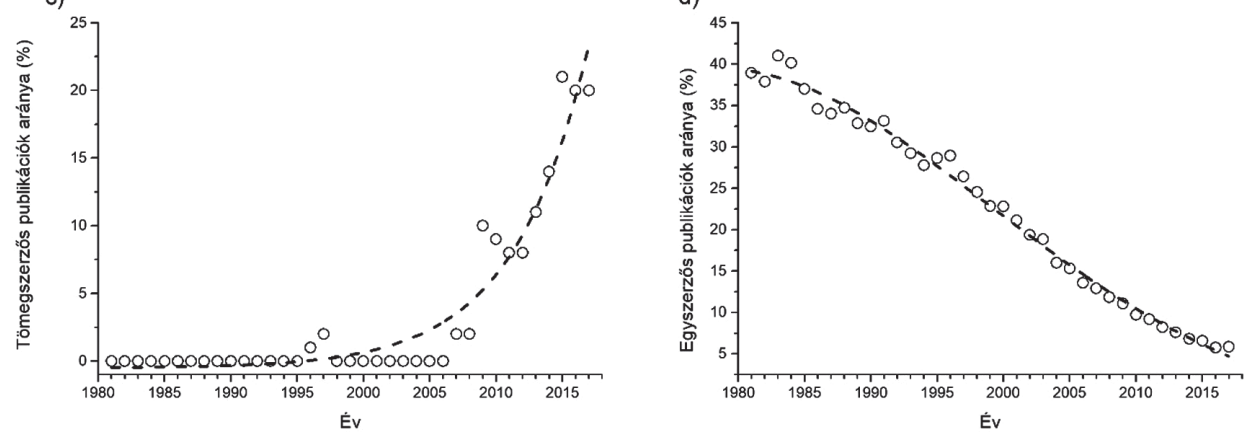

1. ábra. A környezettudomány és ökológiatudomány részterületen a publikációk számának (a), a publikációk átlagos szerzőszámának (b), a tömegszerzős ( $>50$ szerző) publikációk arányának (c) és az egyszerzős publikációk arányának (d) változása a nyolcvanas évektől napjainkig (ISI Web of Science adatbázis ,environmental sciences” és ,ecology” tudomány-részterület kategória)

Azonban, a publikációk átlagos szerzőszámának növekedése származhat a szerzöségi kritériumok nem következetes alkalmazásából, az egyre gyakoribb ki nem érdemelt szerzőségből is (Logan et al., 2017). Számos tudományos társaság, folyóirat megfogalmazta a szerzőséggel szemben támasztott ajánlásait, követelményeit (Logan et al., 2017). Az egyik leghíresebb, az Orvosi Folyóiratok Szerkesztőinek Nemzetközi Bizottsága által megfogalmazott követelményrendszer, az ún. Vancouveri dokumentum (Logan et al., 2017). Eszerint a szerzőség az alábbi négy kritérium egyidejủ teljesítésén alapul: 1. érdemi hozzájárulás a kutatás koncepciójához vagy tervéhez; vagy az adatok gyüjtéséhez, elemzéséhez vagy interpre- 
tációjához; 2. a kézirat első változatának megírása vagy a kézirat szellemi tartalmának alapos revíziója; 3 . a kézirat megjelenésre elfogadott verziójának végleges jóváhagyása; 4 . felelősségvállalás a kutatás minden részletéért, biztosítva a kutatás bármely részletére kiterjedő hitelességet és integritást (ICMJE Recommendations, 2017). E követelményrendszer szerint az érdemi, szellemi hozzájárulás nélkülözhetetlen a szerzőséghez. Kizárólag az adatgyüjtésben való részvétel, a kutatással összefüggő, de nem kreatív feladat végzése, pusztán a kutatási téma és/vagy a kutatócsoport vezetése, a vizsgálathoz támogatás szerzése, vagy csak a kézirat első verziójának megírása, annak javítása, szerkesztése nem meríti ki a szerzőség kritériumait. Számos, a környezettudomány és ökológia terület vezető tudományos folyóirata (például Science, Frontiers in Ecology and Evolution) is elfogadta és alkalmazni kezdte a fenti kritériumrendszert.

A jelenleg általánosan elfogadott tudományos teljesítményt mérő módszer, a publikációk után járó kreditek (tudománymetriai mérőszámok) súlyozatlan, automatikus hozzárendelése a publikáció valamennyi szerzőjéhez szintén hozzájárul a szerzőségi kritériumok nem következetes alkalmazásához, és a sokszerzős közlemények számának és a publikációk átlagos szerzőszámának kirívó növekedéséhez (Lozano, 2013).

\section{MAGYAR SZERZŐK PUBLIKÁCIÓINAK ÁTLAGOS SZERZŐSZÁMA}

A szerzőséggel szemben támasztott egyértelmü követelmények ellenére az, hogy egy adott publikációban ki legyen szerző, és ki nem, nemcsak tudományterületek között, hanem országok között is jelentősen eltérhet. A környezettudomány és ökológiatudomány részterületen is megfigyelhető, hogy a nyolcvanas évektöl a magyar levelezési címü szerzők publikációinak átlagos szerzőszáma a többi, magyar levelezési című szerzőt nem tartalmazó publikáció átlagos szerzőszámához képest szignifikánsan nagyobb mértékben nőtt (2. ábra; ANCOVA: $\mathrm{F}_{2,68}=68,572$, $\mathrm{p}<0,001)$. A publikációk szerzőszámának mediánját elemezve is hasonló összefüggést kapunk (ANCOVA: $\mathrm{F}_{1,71}=9,759, \mathrm{p}=0,003$ ).

Nem valószínü, hogy a magyar szerzők a nemzetközi trendhez képest nagyobb arányban folytatnának multidiszciplináris kutatásokat, hozzájárulva az átlagos szerzőszám növekedésében mutatkozó szignifikáns különbséghez. Sokkal valószínübb, hogy a magyar levelezési címủ szerzők a tudománymetriai méröszámaik maximalizálására való törekvésükkor a szerzőségi kritériumokat nem következetesen alkalmazzák. Hiszen a publikációk szerzőszámának növekedésével nő a valószínüsége annak, hogy olyan is társszerzőként szerepel a közleményben, aki nem teljesíti a szerzőségi kritériumokat (Logan et al., 2017). Egy felmérés szerint a többszerzős ökológiai publikációk 78\%-a nevesített legalább egy olyan társszerzőt, aki nem teljesítette az ICMJE feltételeit (Logan et al., 2017). 


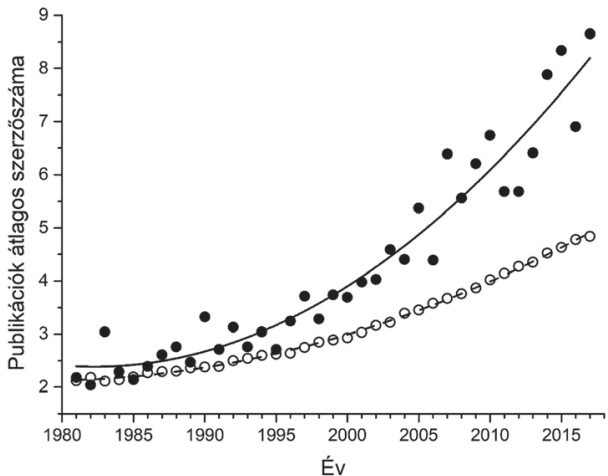

2. ábra. A környezettudomány és ökológiatudomány részterületen a magyar levelezési címủ szerzők publikációinak (•) és a magyar levelezési című szerzőt nem tartalmazó publikációk (○) átlagos szerzőszámának változása a nyolcvanas évektől napjainkig (ISI Web of Science adatbázis „environmental sciences” és „ecology” tudomány-részterület kategória)

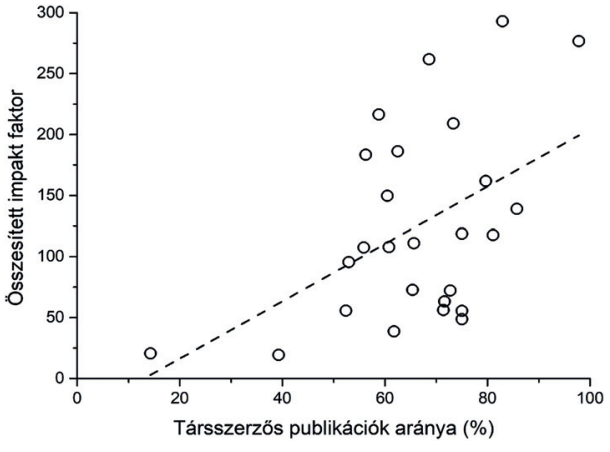

3. ábra. Szupraindividuális biológiával foglalkozó, az MTA Biológiai Tudományok

Osztályának doktori eljárásra vonatkozó minimális követelményeit teljesítő, negyven év feletti, aktív kutatók összesített impaktfaktora és az impaktfaktorral rendelkező folyóiratban megjelent társszerzős (nem elsőszerzős) tudományos publikációinak aránya (\%) közötti összefüggés (publikációk: Magyar Tudományos Müvek Tára, folyóirat adott évi impaktfaktora: Journal Citation Reports)

Tizenhárom, szupraindividuális biológiával foglalkozó tudományos mühely 26, a Magyar Tudományos Akadémia Biológiai Tudományok Osztályának doktori eljárásra vonatkozó minimális követelményeit teljesítő, negyven év feletti, véletlenszerüen kiválasztott aktív kutatójának összesített impaktfaktora és a kutató impaktfaktorral rendelkező folyóiratban megjelent társszerzős (nem elsőszerzős) tudományos publikációinak aránya közötti szignifikáns pozitív összefüggés (3. ábra; $\mathrm{F}_{1,25}=7,348, \mathrm{p}=0,012, \mathrm{R}^{2}=0,202$ ) azt sejteti, hogy a tudománymetriai mérőszámok (a vizsgált esetben az összesített impaktfaktor) maximalizálásának leghatékonyabb módja, ha minél több publikációban társzerzőként szerepel az adott kutató. Az ökológia területén általánosan elfogadott és bizonyított, hogy az első szerző érdemi hozzájárulása a publikációhoz a legnagyobb, ő fordítja a legtöbb időt és energiát az adott kutatásra (Duffy, 2017; Logan et al., 2017). A társszerzők között viszont a szerzőségi követelményeket nem teljesítő kutatók is megjelennek. Egy vizsgálat szerint a hét- vagy többszerzős ökológiai publikációk legalább egy érdemtelenül nevesített társszerzőt tartalmaztak, és a szerzőségi kritériumok nem teljesítése gyakoribb volt a többszerzős cikkekben (Logan et al., 2017). A kutatás szerint a ki nem érdemelt szerzőség leggyakoribb esetei az ajándékként, honoráriumként adott szerzőség (guest/gift/honorary authorship), amikor például az adott kutató csak az adatgyüjtésben vett részt, vagy csak a kutatás elvégzéséhez szerzett támogatást, vagy csak a kézirat stilisztikai, nyelvtani javítását végezte, 
vagy a kutatást végzők felettese, vezetője volt (kutatócsoport-vezető, intézetvezető, doktori iskola vezetője, tanszékvezető, témavezető stb.; ún. enforced authorship), anélkül, hogy érdemi szellemi hozzájárulása lett volna a publikációhoz, és teljesítette volna az összes szerzőségi követelményt (Logan et al., 2017).

\section{A SZERZŐSÉGI KRITÉRIUMOK BE NEM TARTÁSÁNAK KÖVETKEZMÉNYEI}

A szerzőségi kritériumok be nem tartása és ebből adódóan a ki nem érdemelt szerzőség az etikai problémákon kívül a tudományos életet is veszélyezteti. A szerzőséget érintő visszaélések csökkentik a szerzőség presztízsét, megnehezítik a publikációval járó felelősség megállapítását, de veszélyeztetik a tudományos kommunikációs rendszer hitelességét és a tudományos teljesítmény objektív megítélését is (Cronin, 2001). A napjainkban általánosan elfogadott, a szerzők hozzájárulását mellőző, súlyozatlan kredit-hozzárendelésen alapuló tudományos teljesítményt mérő módszer igazságtalan, hiszen figyelmen kívül hagyja a szerzők eltérő mértékü hozzájárulását, elősegíti a szerzőséget érintő visszaéléseket, és alkalmatlan az eltérő kollaborációs profillal rendelkező vagy eltérő létszámú csoportban dolgozó kutatók tudományos teljesítményének objektív értékelésére, összehasonlítására (Vavryčuk, 2018). A tudományos teljesítmény objektív értékelése még nehezebb, szinte lehetetlen olyan esetben, ha nemcsak a kutatók kollaborációs profilja vagy a kutatócsoport létszáma, de a szerzőségi kritériumok betartása is lényegesen különbözik a csoportok között. A súlyozatlan kredit-hozzárendelésen alapuló módszerrel egy nagyobb létszámú, a szerzőségi kritériumokat be nem tartó kutatócsoport valamennyi tagja több, a publikációk után járó kreditet tud szerezni, mint egy kisebb létszámú és a szerzőségi kritériumokat következetesen betartó kutatócsoport tagjai. A fentiekből következik, hogy a tudományos teljesítmény értékelése során paradigmaváltásra van szükség, a szerzői hozzájárulás mértékének figyelembevétele elengedhetetlen a publikációk után járó kreditek (tudománymetriai mérőszámok) elosztásánál (Lozano, 2013).

\section{ÚJ SZEMLÉLETŰ TUDOMÁNYOS TELJESÍTMÉNYÉRTÉKELÉSI MÓDSZER}

Ahhoz, hogy az új szemléletü, a szerzői hozzájárulást is figyelembe vevő tudományos teljesítményértékelési módszert alkalmazni tudjuk, a szerzőknek a publikáció elkészülése során nyújtott hozzájárulását meg kell határozni, és ezt a publikációban is jelezni kell, hogy ez az olvasók, de a szerzők számára is egyértelmü legyen (Lozano, 2013; Duffy, 2017). A publikáció szerzőinek sorrendje erre alkalmatlan, hiszen a szerzők sorrendjét többféleképpen értelmezhetjük. Például az utolsó szerző tölthet be meghatározó szerepet, de lehet az a szerző is, aki 
a legkisebb mértékben járult hozzá a publikációhoz. A tudományos folyóiratok többsége által megkövetelt szerzői hozzájárulás (Author Contributions) gyakran túl rövid, túl általános, így ez alapján sem lehet egyértelmüen eldönteni a szerzők hozzájárulásának mértékét, sőt egy felmérés szerint a szerzői hozzájárulás csak az esetek 41\%-ában tükrözte hitelesen az elvégzett feladatokat (Duffy, 2017). A szerzők hozzájárulásának mértékét a publikáción belül kell feltüntetni, hiszen a kéziratot valamennyi szerző átolvassa, véleményezi, szerkeszti, így biztosítható, hogy valamennyi szerző ugyanúgy értelmezze a hozzájárulás mértékét. Ahogyan ezt már korábban is javasolták, a publikáción belül erre a legalkalmasabb hely a köszönetnyilvánítás (Tscharntke et al., 2007).

A publikációk után járó kreditek szerzői hozzájáruláson alapuló elosztására kidolgozott módszer adott, és négy alapesetet különböztet meg (Tscharntke et al., 2007): 1. a szerzői sorrend határozza meg a publikáció után járó kredit elosztását, 2. a szerzők egyenlő mértékben járultak hozzá a publikációhoz, így egyenlő mértékben részesednek a kreditből, 3. az első és az utolsó szerző hangsúlyozása, 4. a százalékosan megadott szerzői hozzájárulás szerint történik a kredit elosztása. A módszerrel kezelhetők azok az esetek is, amikor kettő vagy több szerző azonos mértékben járult hozzá a publikációhoz, vagy amikor az első szerzőn kívül a kapcsolattartó szerző, illetve egy kitüntetett szerző hozzájárulását szeretnék hangsúlyozni. Azonban a kreditelosztás módját mindig egyértelmúen jelölni kell a köszönetnyilvánításban (Tscharntke et al., 2007). Ezt a módszert a publikáció után járó impaktfaktor szerzők közötti elosztására dolgozták ki, de használható egyéb tudománymetriai mérőszámok (publikációk száma, D1-es vagy Q1-es publikációk száma, független idézetek száma) esetén is. Sőt, napjainkban már létezik egy olyan kifinomult módszer is, amely segítségével a fenti tudománymetriai mérőszámokon kívül a h-index értéke is súlyozható a szerzői hozzájárulás mértékével (Vavryčuk, 2018). A szerzői hozzájárulás százalékos értéke a Magyar Tudományos Mủvek Tárában rögzíthető lenne, hiszen a korábbi verzióban erre lehetőség volt, így a szerzői hozzájárulással súlyozott tudománymetriai méröszámok könnyen számolhatók lennének. Azaz, a szerzői hozzájárulás mértékét figyelembe vevő tudományos teljesítményértékelés eszköztára rendelkezésre áll, csak az eddigi szemlélet megváltoztatására van szükség.

A szemléletváltással, a tudományos teljesítmény értékelésekor a szerzői hozzájárulás mértékének figyelembevételével automatikusan megakadályozható a szerzőségi kritériumok be nem tartásából adódó indokolatlan szerzőszám-felduzzasztás, hiszen a publikációk érdemi szerzői ellenérdekeltek lesznek a szerzőszám növekedésében (Vavryčuk, 2018). A szemléletváltással a tudományos teljesítmény reálisabb megítélése és a tárgyilagos összehasonlítás is megvalósítható, eltüntethető a különböző kooperációs jellemzőkkel rendelkező kutatók tudományos minősítésében jelenleg fennálló aránytalanság is (Vavryčuk, 2018). A paradigmaváltáshoz a legfontosabb a kutatók szerzőségi kritériumokkal kapcsolatos szemléletbeli 
változása, valamint az oktatás, a fiatal kutatók figyelmének felhívása a helyes publikációs gyakorlatra, etikára. Szemléletváltásra van szükség a pályázatok, a tudományos minősítési eljárások és a tudományos fokozatok vagy címek megszerzésére irányuló eljárások során is, hiszen ezek gyakran az első és utolsó szerzöséget, illetve a levelező szerzőséget kezelik csak kitüntetetten (például: Nemzeti Kutatási, Fejlesztési és Innovációs Hivatal pályázatai, Magyar Tudományos Akadémia Kutatóközpontjainak tudományos minősítési szabályzatai, az MTA doktora tudományos cím követelményrendszerét meghatározó szabályzatok).

Azonban a publikáció szerzőinek az alapvető és elidegeníthetetlen joga a hangsúlyos, kitüntetett szerzői szerepek, a szerzői hozzájárulásuk mértékének a meghatározása. Ezt a jogot és a meghatározott hozzájárulás mértékét a tudományos élet valamennyi szereplőjének (kutatók, pályázati és minősítési döntéshozók) tiszteletben kell tartania és el kell fogadnia, azt nem írhatják felül. A javasolt, új szemléletü, a szerzői hozzájárulást figyelembe vevő tudományos teljesítményértékelési módszer életbe léptetése elengedhetetlen a modern, ismeretalapú kutatás erkölcsi értékeinek, normáinak és a kutatói társadalom felelősségének megőrzéséhez. Ebben kulcsszerepe van a magyar tudományt képviselő Magyar Tudományos Akadémiának. Csak bizakodhatunk, hogy a vázolt rendszer bevezetésében, megvalósításában meghatározó szerepet betöltők támogatni fogják a változtatásokat.

\section{IRODALOM}

Cronin, B. (2001): Hyperauthorship: A Postmodern Perversion Or Evidence of a Structural Shift in Scholarly Communication Practices? Journal of the American Society for Information Science and Technology, 52, 558-569. DOI: 10.1002/asi.1097, https://bit.ly/2MG1xwX

Duffy, M. A. (2017): Last and Corresponding Authorship Practices in Ecology. Ecology and Evolution, 7, 8876-8887. DOI: 10.1002/ece3.3435, https://www.ncbi.nlm.nih.gov/pmc/articles/ PMC5677469/

ICMJE Recommendations (2017): http://www.icmje.org/recommendations/

Logan, J. M. - Bean, S. B. - Myers, A. E. (2017): Author Contributions to Ecological Publications: What Does It Mean to Be an Author in Modern Ecological Research? PLOS ONE, 12, e 0179956. DOI: 10.1371/journal.pone.0179956, https://journals.plos.org/plosone/article?id=10.1371/ journal.pone. 0179956

Lozano, G. A. (2013): The Elephant in the Room: Multi-Authorship and the Assessment of Individual Researchers. Current Science, 105, 443-445. http://www.currentscience.ac.in/ Volumes/105/04/0443.pdf

Tscharntke, T. - Hochberg, M. E. - Rand, T. A. et al. (2007): Author Sequence and Credit for Contributions in Multiauthored Publications. PLOS Biology, 5, e18. DOI: 10.1371/journal. pbio.0050018, https://journals.plos.org/plosbiology/article?id=10.1371/journal.pbio.0050018

Vavryčuk, V. (2018): Fair Ranking of Researchers and Research Teams. PLOS ONE, 13, e0195509. DOI: 10.1371/journal.pone.0195509, https://journals.plos.org/plosone/article?id=10.1371/ journal.pone.0195509 